\title{
AKAD MUDHARABAH MUTLAQAH DALAM PRAKTIK PERBANKAN SYARIAH
}

\author{
Fariz Al-Hasni \\ Universitas Islam Negeri Mataram
}

\begin{abstract}
Abstrak
Akad pada dasarnya pertemuan antara para pihak, yang di mana salah satu pihak mengajukan penawaran (ijab) dan pihak lain memberikan jawaban persetujuan atas tanggapan dari penawaran tersebut (kabul), dalam bentuk pernyataan kehendak masing-masing pihak yang tidak berhubungan satu sama lain. Tujuannya menimbulkan akibat hukum pada objek yang diakadkan oleh kedua belah pihak. Salah satu pengimplementasian akad dalam dunia perbankan syariah adanya bentuk kerjasama dengan menggunakan akad mudharabah atau yang sering dikenal dengan istilah sistem bagi hasil. Mengingat, akad menimbulkan akibat hukum bagi kedua belah pihak, maka para pihak harus cermat di dalam memahami isi akad. Sehingga, kedepannya tidak menimbulkan persoalan yang dapat merugikan salah satu pihak. Dengan demikian, sangatlah penting untuk diketahui bagaimana penerapan akad mudharabah dalam praktik perbankan syariah agar persoalan-persoalan yang timbul di antara kedua belah pihak dapat diminimalisir dan tidak ada yang dirugikan.
\end{abstract}

Kata Kunci: Mudharabah, Akad, Perbankan Syariah

\section{A. PENDAHULUAN}

Bank syariah merupakan bank yang melaksanakan kegiatan usaha berdasarkan prinsip syariah, yaitu aturan perjanjian berdasarkan hukum Islam antara bank dan pihak lain untuk penyimpanan dana dan atau pembiayaan kegiatan usaha, atau kegiatan lainnya yang dinyatakan sesuai dengan syariah. Dalam menjalankan usahanya bank syariah menggunakan pola bagi hasil yang merupakan landasan utama dalam segala operasinya, baik dalam produk pendanaan, pembiayaan maupun dalam produk lainnya. Produkproduk bank syariah mempunyai kemiripan tetapi tidak sama dengan produk bank konvensional karena adanya pelarangan riba, gharar dan maysir. Oleh karena itu, produkproduk pendanaan dan pembiayaan seperti pembiayaan modal kerja dan investasi dalam bentuk akad bagi hasil pada bank syariah harus menghindari unsur-unsur yang dilarang tersebut. ${ }^{1}$

${ }^{1}$ Ascarya, Akad dan Produk Bank Syariah, Ed. I, (Jakarta: PT. Raja Grafindo Persada, 2007), hlm. v 
Prinsip bagi hasil (profit sharing) merupakan karekteristik umum dan landasan dasar bagi operasional bank syari'ah secara keseluruhan, secara syari'ah prinsip berdasarkan pada kaidah al mudharabah. Berdasarkan prinsipinibanksyari'ah akan berfungsi sebagai mitra baik dengan penabung demikianjuga denganpengusahayang meminjam dana. Dengan penabung, bank akan bertindak sebagai mudharib (pengelola) sementara penabung sebagai penyandang dan (shahibul mal). Antara keduanya diadakan akad mudharabah yang menyatkan pembagian keuntungan masingmasing pihak. $^{2}$

\section{B. PEMBAHASAN}

\section{Definisi Mudharabah}

Mudharabah berasal dari kata dharb, berarti memukul atau berjalan. Pengertian memukul atau berjalan ini lebih tepatnya adalah proses seseorang memukulkan kakinya dalam menjalankan usaha. Secara teknis, al-mudharabah adalah akad kerjasama usaha antara dua pihak di mana pihak pertama (shahibul maal) menyediakan seluruh (100\%) modal, sedangkan pihak lainnya menjadi pengelola. Keuntungan usaha secara mudharabah dibagi menurut kesepakatan yang dituangkan dalam kontrak, sedangkan apabila rugi ditanggung oleh pemilik modal selama kerugian itu bukan akibat

${ }^{2}$ Muhammad, Manajemen Bank Syari'ah, cet. ke-2, (Yogyakarta: Unit Penerbit dan Percertakan Sekolah Tinggi Ilmu Manajemen YKPN, 2011), hlm. 109-110 kelalaian si pengelola. Seandainya kerugian itu diakibatkan karena kecurangan atau kelalaian si pengelola, si pengelola harus bertanggung jawab atas kerugian tersebut. ${ }^{3}$ Mudharabah dapat berupa mudharabah mutlaqah atau mudharabah muqayyadah. ${ }^{4}$

Sehubungan dengan pembagian tersebut dalam pembahasan ini, penulis akan lebih memusatkan perhatian pada akad mudharabah mutlaqah dalam praktik perbankan syari'ah.

\section{Pengertian Mudharabah Mut- laqah}

Mudharabah mutlaqah atau yang disebut juga dengan istilah unrestricted mudharabah merupakan bentuk kerja sama yang memberikan kebebasan kepada mudharib untuk mengelola modal dalam bentuk usaha apapun yang bisa mendatangkan keuntungan selama tidak bertentangan dengan prinsip-prinsip syariah. Pada prinsipinya, pihak modal tidak berhak mengelola persekutuan secara mutlak. Namun pihak mudharib lah yang berhak mengelola, sebab mudaharabah merupakan percampuran antara badan pengelola (pekerja) dengan modal, tetapi bukan pemilik modal. Sehingga pemodal

${ }^{3}$ Muhammad Syafi'I Antonio, Bank Syari'ah: Dari Teori ke Prektik, cet. ke-1, (Jakarta: Gema Insani, 2001), hlm. 95

${ }^{4}$ Wangsawidjaja Z, Pembiayaan Bank Syariah, (Jakarta: PT. Gramedia Pustaka Utama, 2012), hlm. 192 
layaknya pihak yang berada di luar persekutuan (syirkah). ${ }^{5}$

Dalam pembahasan fiqih ulama salafus saleh sebagaimana yang dikutip oleh Muhammad Syafi'I Antonio, seringkali dicontohkan dengan ungkapan if'al ma syi'ta (lakukanlah sesukamu) dari shahibul mal ke mudharib yang memberi kekuasaan yang sangat besar. ${ }^{6}$

\section{Landasan Syari'ah}

Secara umum, landasan syari'ah al-mudharabah lebih mencerminkan anjuran untuk melakukan usaha. Hal ini tampak dalam ayat dan hadits berikut ini:?

a. al-Qur'an

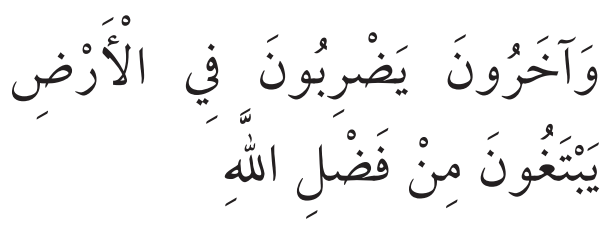

“...dan orang-orang yang berjalan di muka bumi mencari sebagian karunia Allah...". (QS. alMuzammil (73): 20

Yang menjadi wajhud-dilalah (وَجْْهُ الدِّلََلَ) atau argument dari surah tersebut adalah adanya kata yadhribun yang sama dengan akar kata

${ }^{5}$ Burhanuddin S, Hukum Kontrak Syariah, cet. ke-1, (Yogyakarta: BPFE-Yogyakarta, 2009), hlm. 116

${ }^{6}$ Muhammad Syafi'I Antonio, Bank Syari'ah..., hlm. 97

${ }^{7}$ Ibid., hlm. 95

${ }^{8}$ Departemen Agama RI, al-Qur'an Transliterasi Per Kata dan Terjemahan Per Kata, (Bekasi: Cipta Bagus Segara, 2011), hlm. 575 mudharabah yang berarti melakukan sesuatu perjalanan usaha. ${ }^{9}$

b. al-Hadits

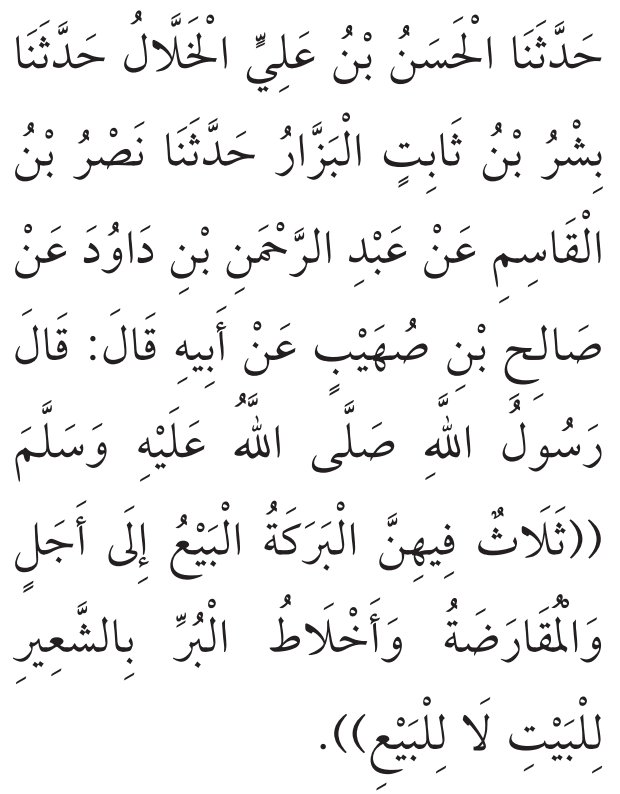

Telah menceritakan kepada kami Al Hasan bin Ali Al Khallal berkata, telah menceritakan kepada kami Bisyr bin Tsabit Al Bazzarberkata, telah menceritakan kepada kami Nashr bin Al Qasim dari <Abdurrahman bin Dawud dari Shalih bin Shuhaib dari Bapaknya ia berkata, Rasulullah $S A W$ bersabda: "Tiga hal yang di dalamnya terdapat barakah; jual beli yang memberi tempo (secara tangguh), muqaradhah (mudharabah), dan campuran gandum dengan jelai (tepung) untuk di konsumsi orang-orang rumah (keperluan rumah), bukan untuk dijual". ${ }^{10}$

${ }^{9}$ Muhammad Syafi'i Antonio, Bank Syari'ah..., hlm. 95

${ }^{10}$ Ibnu Majah, Sunan Ibnu Majah, "Kitab atTijarah", terj. Lembaga Ilmu dan Dakwah serta 


\section{c. Ijma'}

Imam Zailai sebagaimana yang dikutip oleh Muhammad Syafi'I Antonio, telah menyatakan bahwa para sahabat telah berkonsensus ${ }^{11}$ terhadap legitimasi ${ }^{12}$ pengolahan harta yatim secara mudharabah. Kesepakatan para sahabat ini sejalan dengan spirit hadits yang dikutip Abu Ubaid. ${ }^{13}$

\section{d. Landasan Hukum}

Sebagai landasan hukum pembiayaan berdasarkan akad mudharabah antara lain adalah Pasal 19 ayat (1) huruf $c$ dan ayat (2) huruf c serta Pasal 21 huruf b angka 1 UU Perbankan Syariah, Fatwa DSN No. 07/DSN-MUI/IV/2000 tentang Pembiayaan Mudharabah (Qirad) dan PBI No. 7/6/PBI/2005 tentang Transparansi Informasi Produk Bank danPenggunaanData PribadiNasabah beserta ketentuan perubahannya, serta PBI No. 9/19/PBI/ 2007 tentang Pelaksanaan Prinsip Syariah dalam Kegiatan Penghimpunan Dana dan Penyaluran Dana serta Pelayanan Jasa Bank Syariah berikut perubahannya dengan PBI No. 10/16/PBI/2008. ${ }^{14}$

Publikasi Sarana Keagamaan, Ensiklopedia Hadits versi Dekstop: Sunan Ibnu Majah, (Jakarta: Lidwa Pusaka, 2015), no. 2280. Hadis diriwayatkan oleh Shalih bin Shuhaib.

${ }^{11}$ Bersepakat

${ }^{12}$ Keterangan yang mengesahkan

${ }^{13}$ Muhammad Syafi'I Antonio, Bank Syari'ah..., hlm. 96

${ }^{14}$ Wangsawidjaja Z, Pembiayaan Bank..., hlm. 195-196
Disamping ketentuan tersebut, bagi pembiayaan mudharabah berlaku perlakuan akuntansi sebagaimana diatur dalam Pernyataan Standar Akuntansi Keuangan (PSAK) No. 105 tentang Akuntansi Mudharabah dan lampiran SEBI No. 5/26/BPS tanggal 27 Oktober 2003 tentang Pedoman Akuntansi Perbankan Syariah Indonesia (PAPSI). Pembiayaan berdasarkan akad mudharabah sebagaimana diuraikan, berlaku bagi Bank Umum Syariah, Unit Usaha Syariah dan Bank Pembiayaan Rakyat Syariah. ${ }^{15}$

\section{Rukun dan Syarat}

Sebagaimana akad pada umumnya, rukun merupakan unsurunsuryangmenentukan terbentuknya akad. Untuk dapat menjadi rukun, sesuatu harus memenuhi syarat sebagai rukun. ${ }^{16}$ Adapun rukun dan syarat yang berlaku dalam mudharabah adalah sebagai berikut:

a. Penyedia dana (shahibul maal) dan pengelola (mudharib) harus cakap hukum;

b. Pernyataan ijab dan qabul harus dinyatakanoleh para pihakuntuk menunjukkan kehendak mereka dalam mengadakan kontrak (akad) dengan memperhatikan hal-hal berikut:

\footnotetext{
${ }^{15}$ Ibid., hlm. 196

${ }^{16}$ Burhanuddin S, Hukum Kontrak..., hlm.
} 113 
1) Penawaran dan penerimaan harussecara eksplisit (gambling/ tegas) menunjukkan tujuan kontrak (akad);

2) Penerimaan dari penawaran dilakukan pada saat kontrak;

3) Akad dituangkan secara tertulis, melalui korespodensi atau dengan menggunakan cara-cara komunikasi modern.

c. Keuntungan mudharabah adalah jumlah yang didapat sebagai kelebihan dari modal. Syarat keuntungan berikut ini harus dipenuhi:

1) Harus diperuntukkan bagi kedua pihak dan tidak boleh disyaratkan untuk satu pihak;

2) Bagiankeuntunganproporsional bagi setiap pihak harus diketahui dan dinyatakan pada waktu kontrak disepakati dan harus dalam bentuk presentase (nisbah) dari keuntungan sesuai kesepakatan. Perubahan nisbah harus berdasarkan kesepakatan;

3) Penyedia dana menanggung semua kerugian akibat dari mudharabah dan pengelola tidak boleh menanggung kerugian apa pun kecuali diakibatkan dari kesalahan disengaja, kelalaian, atau pelanggaran kesepakatan.

d) Modal ialah sejumlah uang dan/ atau aset yang diberikan oleh penyedia dana kepada mudharib untuk tujuan usaha dengan syarat sebagai berikut:

1) Modal harus diketahui jumlah dan jenisnya;

2) Modal dapat berbentuk uang atau barang yang dinilai. Jika modal diberikan dalam bentuk aset tersebut harus dinilai pada waktu akad;

3) Modal tidak dapat berbentuk piutang dan harus dibayarkan kepada mudharib, baik secara bertahap maupun tidak, sesuai dengan kesepakatan dalam akad.

e) Kegiatan usaha oleh pengelola (mudharib), sebagai perimbangan modal yang disediakan oleh penyedia dana, harus memperhatikan hal-hal berikut:

1) Kegiatan usaha adalah hak eksklusif (khusus/terpisah) mudharib, tanpa campur tangan penyedia dana, tetapi ia mempunyai hak untuk melakukan pengawasan;

2) Penyedia dana tidak boleh mempersempit tindakan pengelola sedemikian rupa yang dapat menghalangi tercapainya tujuan mudharabah, yaitu keuntungan;

3) Pengelola tidak boleh menyalahi hukum syari'ah Islam dalam tindakannya yang berhubungan dengan mudharabah, dan harus 
mematuhi kebiasaan yang berlaku dalam aktivitas itu. ${ }^{17}$

\section{Resiko Mudharabah}

Resiko yang terdapat dalam mudharabah, terutama pada penerapannya dalam pembiayaan, relatif tinggi. Diantaranya:

a. Side streaming, nasabah menggunakan dana itu bukan seperti yang disebut dalam kontrak;

b. Lalai dan kesalahan yang disengaja;

c. Penyembunyian keuntungan oleh nasabah bila nasabahnya tidak jujur. $^{18}$

\section{Aplikasi dalam Perbankan Syari'ah}

Mudharabah biasanya diterapkan pada produk-produk pembiayaan dan pendanaan. Pada sisi penghimpunan dana, mudharabah diterapkan pada:

a. Tabungan berjangka, yaitu tabungan yang dimaksudkan untuk tujuan khusus, seperti tabungan haji, tabungan kurban, dan sebagainya;

b. Deposito biasa;

${ }^{17}$ Muhammad, Manajemen Pembiayaan Mudharabah di Bank Syariah: Strategi Memaksimalkan Return dan Meminimalkan Return dan Meminimalkan Resiko Pembiayaan di Bank Syari'ah sebagai Akibat Masalah Agency, ed. ke-1, (Jakarta: Rajawali, 2008), hlm.58-60, lihat juga Adiwarman Karim, Bank Islam: Analisis Fiqih dan Keuangan, cet. ke-7, (Jakarta: PT. Raja Grafindo Persada, 2010), hlm. 205

${ }^{18}$ Muhammad Syafi'I Antonio, Bank Syari'ah..., hlm. 98 c. Deposito spesial (special investment), di mana dana yang dititipkan nasabah khusus untuk bisnis tertentu, misalnya murabahah atau ijarah saja. ${ }^{19}$

Adapun pada sisi pembiayaan mudharabah mutlaqah diterapkan untuk:

Penerapan mudharabah mutlaqah dapat berupa tabungan dan deposito sehingga terdapat dua jenis penghimpunan dana yaitu: tabungan mudharabah dan deposito mudharabah. Berdasarkan prinsip ini tidak ada pembatasan bagibank dalam menggunakan dana yang dihimpun. ${ }^{20}$ Mudharabah mutlaqah tergolong dalam investasi yang tidak terikat. Investasi ${ }^{21}$ tersebut bukan merupakan kewajiban atau equitas bank, karena bank tidak berkewajiban mengembalikan dana apabila terjadi kerugian pengelolaan dana yang bukan disebabkan kelalaian atau kesalahan bank sebagai mudharib. Dan dalam perbankan syariah jenis mudharabah muthlaqah (investasi tidak terikat) antara lain investasi tidak terikat dari bukan bank dan Investasi tidak terikat dari bank lain. ${ }^{22}$

\footnotetext{
${ }^{19}$ Ibid., hlm. 97

${ }^{20}$ Janji Mustawa, "Mudharabah Mutlaqah”, dalam http://www.sanabila. com/2015/08/mudharabah-muthlaqah.html, diakses tanggal 15 April 2016

${ }^{21}$ Penanaman modal untuk satu atau lebih aktiva yang dimiliki dan memiliki jangka waktu lama, dengan harapan mendapatkan keuntungan di masa-masa yang akan datang.

${ }^{22}$ Riska Herliyani, "Makalah Ekonomi", dalam http://riskaherliyani.blogspot.
} 
a. Investasi Tidak Terikat Dari Bukan Bank

Investasi tidak terikat dari bukan

bank antara lain:

1) Tabungan mudharabah, yaitu investasi tidak terikat pihak ke tiga pada bank syariah yang penarikannya hanya dapat dilakukan menurut syarat tertentu yang disepakati.

2) Deposito mudharabah adalah investasi tidak terikat pihak ketiga pada bank syarian yang penarikannya hanya dapat dilakukan pada waktu tertentu dengan pembagian hasil sesuai dengan nisbah yang telah disepakati di muka antara nasabah dengan bank syariah yang bersangkutan.

Penyajian,

1) Investasi tidak terikat dari pihak ketiga disajikan sebesar jumlah nominalnya untuk masingmasing bentuk investasi tidak terikat, antara lain tabungan mudharabah dan deposito mudharabah.

2) Bagi hasil investasi tidak terikat yang sudah diperhitungkan dan telah jatuh tempo tetapi belum diserahkan kepada nasabah disajikan dalam pos kewajiban segera.

co.id/2014/04/contoh-makalah-ekonomi. html, diakses tanggal 15 April 2016.
3) Bagi hasil investasi tidak terikat yang sudah diperhitungkan pada akhir periode tetapi belum jatuh tempo disajikan dalam pos bagi hasil yang belum dibagikan. ${ }^{23}$

b. Investasi Tidak Terikat Dari Bank Lain

Jenis Investasi tidak terikat dari bank lain:

1) Tabungan mudharabah, investasi tidak terikat dari bank lain pada bank syari'ah yang penarikkannya hanya dapat dilakukan menurut syarat tertentu yang disepakati.

2) Deposito mudharabah, Investasi tidak terikat dari bank lain pada bank syariah yang penarikannya hanya dapat dilakukan pada waktu tertentu dengan pembagian hasil sesuai dengan nisbah yang telah disepakati dimuka antara nasabah dengan bank syari'ah yang bersangkutan. ${ }^{24}$

c. Sertifikat Investasi Mudharabah Antar Bank Syari'ah

Sertifikat yang digunakan bank sebagai sarana untuk mendapatkan dana dengan prinsip mudharabah.

Penyajian,

1) Investasi tidak terikat dari bank lain disajikan sebesar jumlah nominalnnya untuk

${ }^{23}$ Ibid.

${ }^{24}$ Ibid. 
masing-masing bentuk investasi tidak terikat, antara lain tabungan mudharabah, deposito mudharabah dan Sertifikat IMA.

2) Bagi hasil investasi tidak terikat yang sudah diperhitungkan dan telah jatuh tempo tetapi belum diserahkan kepada nasabah disajikan dalam pos kewajiban segera.

3) Bagi hasil investasi tidak terikat yang sudah diperhitungkan pada akhir periode tetapi belum jatuh tempo disajikan dalam pos bagi hasil yang belum dibagikan. ${ }^{25}$

\section{Ketentuan Umum dalam Produk Mudharabah Mutlaqah}

Ketentuan umum dalam produk mudharabah mutlaqah dapat dipaparkan sebagai berikut:

a. Bank wajib memberitahukan kepada pemilik dana mengenai nisbah dan tata cara pemberitahuan keuntungan dan atau pembagian keuntungan secara resiko yang dapat ditimbulkan dari penyimpanan dana. Apabila telah tercapai kesepakatan; maka hal tersebut harus dicantumkan dalam akad;

b. Untuk tabungan mudharabah, bank dapat memberikan buku tabungan sebagai bukti penyimpanan, serta kartu ATM dan atau alat penarikan lainnya kepada penabung. Untuk

${ }^{25}$ Ibid. deposito mudharabah, bank wajib memberikan sertifikat atau tanda penyimpanan (bilyet) deposito kepada deposan;

c. Tabungan mudharabah dapat diambil setiap saat oleh penabung sesuai dengan perjanjian yang disepakati namun tidak diperkenankan mengalami saldo negatif;

d. Deposito mudharabah hanya dapat dicairkan sesuai dengan jangka waktu yang telah disepakati. Deposito yang diperpanjang, setelah jatuh tempo akan diperlakukan sama seperti deposito baru, tetapi bila pada akad sudah dicantumkan perpanjangan otomatis maka tidak perlu dibuat akad baru.

e. Ketentuan-ketentuan yang lain yang berkaitan dengan tabungan dan deposito tetap berlaku sepanjang tidak bertentangan dengan prinsip syariah. ${ }^{26}$

Deposito mudharabah mutlaqah, pemilik dana tidak memberikan batasan atau persyaratan tertentu kepada bank syariah dalam mengelola investasinya, baik yang berkaitan dengan tempat, cara maupun objek investasinya. Dengan kata lain, bank syariah mempunyai hak dan kebebasan sepenuhnya dalam menginvestasikan mudharabah mutlaqah ini ke berbagai sektor bisnis "26anji Mustawa, "Mudharabah 
yang diperkirakan akan memperoleh keuntungan. Dalam perhitungan bagi hasil deposito mudharabah mutlaqah, basis perhitungan adalah hari bagi sebenarnya, termasuk tanggal tutup buku, namun tidak termasuk tanggal pembukuan deposito mudharabah mutlaqah dan tanggal jatuh tempo. Sedangkan jumlah hari dalam sebulan yang menjadi angka penyebut/angka pembagi adalah hari kalender bulan yang bersangkutan (28 hari, 30 hari, atau 31 hari). ${ }^{27}$

Pembayaran bagi hasil deposito mudharabah mutlaqah dapat dilakukan melalui dua metode, yaitu:

a. Anniversary Date (Tanggal Jadian)

1) Pembayaran bagi hasil deposito dilakukan secara bulanan, yaitu pada tanggal yang sama dengan tanggal pembukaan deposito;

2) Tingkat bagi hasil yang dibayarkan adalah tingkat bagi hasil tutup buku bulan terakhir;

3) Bagi hasil bulanan yang diterima nasabah dapat diafiliasikan ke rekening lainnya sesuai dengan permintaan deposan.

b. End of Month (Akhir Bulan)

1) Pembayaran bagi hasil deposito dilakukan secara bulanan, yaitu pada tanggal tutup buku setiap bulan;
2) Bagihasilbulanpertamadihitung secara proporsional hari efektif termasuk tanggal tutup buku, tetapi tidak termasuk tanggal pembukuan deposito;

3) Bagihasilbulanterakhir dihitung secara proporsional bulan efektif tidak termasuk tanggal jatuh tempo deposito. Tingkat bagi hasil yang dibayarkan adalah tingkat bagi hasil tutup buku bulan terakhir;

4) Jumlah hari sebulan adalah hari kalender bulan yang bersangkutan (28 hari, 29 hari, 30 hari dan 31 hari);

5) Bagi hasil bulanan yang diterima nasabah dapat diafiliasikan ke rekening lainnya sesuai permintaan deposan. ${ }^{28}$

Pencairan deposito mudharabah mutlaqah dengan pembayaran bagi hasil bulanan yang dilakukan sebelum tanggal jatuh tempo, bank syariah dapat mengenakan denda (penalty) kepada nasabah yang bersangkutan sebesar 3\% (tiga persen) dari nominal bilyet deposito mudharabah mutlaqah. Klausul dendan harus ditulis dalam akad dan dijelaskan kepda nasabah pada saat pembukaan deposito mudaharabah mutlaqah semua jangka waktu (1, 3, 6 dan 12 bulan) untuk disepakati bersama oleh nasabah dan bank. Dalam hal ini, bagi hasil yang 
menjadi hak nasabah dan belum dibayarkan, harus dibayarkan.

\section{Berakhirnya Mudharabah}

Lazimnya akad mudharabah akan berakhir setelah tujuannnya dapat tercapai. Namun tujuan mudharabah tercapai, terkadang akad mudharabah dapat dikatakan berakhir karena adanya hal-hal berikut:

a. Tidak terpenuhinya salah satu atau beberapa syarat mudharabah. Jika salah satu syarat mudharabah tidak terpenuhi, maka pengelola yang sudah terlanjur mentasharrufkan modal atas izin pemiliknya berhak mendapatkan upah. Jika dari usaha tersebut mendapatkan keuntungan, maka hasilnya diperuntukkan bagi pemilik modal. Begitupula sebaliknya, apabila mengalami kerugianakan menjaditanggung jawabnya. Ketentuan ini berlaku karena pengelola tidak lebih hanya sebagai pekerja sewaan yang tidak wajib menanggung kerugian, kecuali karena faktor kesengajaan;

b. Pengelola modal (mudharib) dengan sengaja meninggalkan tugas yang diamanahkan kepadanya dan berbuat sesuatu yang bertentangan dengan tujuan akad. Jika demikian yang terjadi, maka pihak pengelola modal bertanggung jawab atas segala kerugian yang dialaminya;

c. Menurut jumhur ulama, mudharabah akan batal jika salah satu pihak meninggal dunia. Apabila yang meninggal pemilik modal (shahibul mal), maka pihak pengelola (mudharib) tidak berhak untuk melanjutkan mudharabah. Namun jika tetap melanjutkan meskipun tanpa izin ahli warisnya, maka tindakannya dianggap ghasap (memanfaatkan sesuatu tanpa izin). Karena itu apabila terjadi kerugian, maka pihak pengelola wajib bertanggung jawab. Sedangkanapabilamendapatkan keuntungan, maka hasilnya dapat dibagi menjadi dua. Jika mudharabah telah batal (fasakh), sedangkan modal syirkah sudah berbentuk barang dagangan ('urud), maka kedua belah pihak boleh menjual agar hasilnya dapat dibagi;

d. Adanya pihak yang kehilangan kecakapan untuk bertasharruf (keahlian mengelola harta), baik karena kehilangan ingatan (gila) maupun sebab-sebab lainnya;

e. Kegiatan usaha yang dijalankan oleh pengelola modal (mudharib) mengalami kerugian, sehingga memungkinkan usaha tersebut mengalami kegagalan dan dinyatakan dalam status kepailitan (muflis); 
f. Abu Hanifah keadaan ini menyebabkan akad mudharabah menjadi batal. ${ }^{29}$

\section{Analisis Akad Mudharabah Mutlaqah dalam Praktik Perbankan}

Dari pemaparan di atas dapat dianalisa, bahwa akad mudharabah mutlqah dalam praktik perbankan dapat dilihat dari beberapa aspek:

a. Aspek Pembiayaan

Akad mudharabah mutlaqah yang dijadikan bahan acuan di dalam menganalisis, ternyata lebih diterapkanpadasisipembiayaanmodal kerja jasa kontruksi, yang tertuang dalam Pasal 1 Perjanjian Mudharabah No. 9072/MDA/VI/2010, di mana nasabah dalam kontrak tersebut menerima amanah pembiayaan syirkah sebesar Rp. 180.000.000,dengan proyeksi pendapatan sebesar Rp. 60.000.000,- dan nisbah yang disepakati bersama, Bank sebesar $6 \%$ sedangkan nasabah sebesar $94 \%$. Adapun proyeksi angsuran setelah dihitung daribesarnya nisbah bank dan proyeksi pendapatan, memperoleh hasil sebesar Rp. 3.600.000,- dengan jangka waktu selama 3 (tiga) bulan.

Pembiayaan yang menjadi acuan di dalam kontrak tersebut menurut hemat penulis lebih mengarah kepada pembiayaan mudharabah muqayyadah, yang dimana mudharabah tersebut

${ }^{29}$ Burhanuddin S, Hukum Kontrak..., hlm. 117-119 merupakan akad kerjasama di mana pemilik modal (shahibul mal) menetapkan syarat tertentu yang harus dipatuhi mudharib baik yang berkaitan dengan tempat kegiatan usaha, jenis usaha, barang yang menjadi objek usaha, waktu dan dari siapa barang tersebut dibeli. ${ }^{30}$ Keuntungan usaha secara mudharabah dibagi menurut kesepakatan yang dituangkan dalam kontrak, sedangkan apabila rugi ditanggung oleh pemilik modal selama kerugian itu bukan akibat kelalaian si pengelola. Apabila, pembiayaan dalam kontrak di atas, disebut sebagai mudharabah mutlaqah, rasanya tidaklah tepat karena mudharabah mutlaqah sendiri tidak sesuaidenganpemaparandiatas, sebab penerapannya secara umum berupa tabungan dan deposito sehingga terdapat dua jenis penghimpunan dana yaitu: tabungan mudharabah dan deposito mudharabah.

Oleh sebab itu, contoh kasus yang tepat dalam mudharabah mutlaqah beradasarkan apa yang dipaparkan di atas dapat dipahami sebagai berikut:

1) Contoh Perhitungan Keuntungan Tabungan Mudharabah: Ibu Ratnaningsih memiliki tabungan Mudharabah di bank syariah A dengan saldo rata-rata bulan Mei sebesar Rp. 15.000.000,00. Perbandingan nisbah antara bank

${ }^{30}$ Dimayuddin Djuwaini, Pengantar Figh Muamalah, cet. ke-2, (Yogyakarta: Pustaka Pelajar, 2010), hlm. 228 
syariah dengan deposan adalah $40 \%$ : $60 \%$. Saldo rata-rata per bulan di seluruh bank syariah A sebesar Rp. 7.500.000.000,00. Kemudian keuntungan bank syariah yang dibagihasilkan adalah Rp. 30.000.000,00. Jadi, Keuntungan Ibu Ratnaningsih

$$
=\quad \text { Saldo rata-rata } \mathrm{Ibu}
$$
Ratnaningsih X Keuntungan Bank Syariah X 60\%) : Saldo rata-rata bank syariah D

$$
=(\text { Rp. } 15.000 .000,00 \quad \mathrm{X}
$$

Rp. $30.000 .000,00 \quad \mathrm{X} \quad 60 \%)$ : Rp. 7.500.000.000,00

$=$ Rp. 36.000,00, 9keuntungan

Ibu Ratnaningsih yang diperoleh selama bulan tsb.)

2) Contoh Perhitungan Keuntungan Deposito Mudharabah

Tn. Arif memiliki deposito mudharabahsebesarRp.20.000.000,00 dengan jangka waktu 1 bulan di bank syariah $Z$. Nisbah antara bank syariah dengan nasabah adalah $45 \%$ : $55 \%$. Saldo rata-rata deposito per bulan di bank syariah $Z$ sebesar Rp. $\quad 10.000 .000 .000,00$. Kemudian pendapatan yang dibagihasilkan bank syariah $Z$ adalah Rp. 500.000.000,00. Jadi, Keuntungan Nasabah

$=$ (Deposito Tn. Arif X Pendapatan Bank Syariah X 55\%) : Saldo rata-rata deposito di bank syariah $=\quad$ Rp. 20.000.000,00 X Rp. 500.000.000,00 X 55\%) : Rp. 10.000.000.000,00

$=$ Rp. 550.000,00, (keuntungan Tn. Arif dari deposito berjangka 1 bulan). ${ }^{31}$

b. Aspek Jaminan

Mengenai jaminan dalam kontrak tersebut yang tertuang dalam pasal 7 tentang Pernyataan dan Jaminan pada dasarnya sudah sesuai dengan peraturan Fatwa DSN Tentang Rahn Tasjily, yang menyatakan bahwa "Rahn Tasjily" disebut juga dengan Rahn Ta'mini, Rahn Rasmi, atau Rahn Hukmi adalah jaminan dalam bentuk barang atas utang, dengan kesepakatan bahwa yang diserahkan kepada penerima jaminan (murtahin) hanya bukti sah kepemilikannya (sertifikat barang), sedangkan fisik barang jaminan tersebut (marhun) tetap berada dalam penguasaan dan pemanfaatan pemberi jaminan (rahin)" ${ }^{32}$

c. Aspek Kelalaian

Pada pasal 6 angka 1 Perjanjian Mudharabah, dijelaskan bahwa kelalaian Nasabah untuk melaksanakan kewajibannya menurut

${ }^{31}$ Fadly Knight, "Penerapan Mudharabah Mutlaqah Dan Muqayadah Dari Sisi Kewajiban Serta Bagi Hasil Pada Bank Syariah”, dalam http: / / fadlyknight.blogspot.co.id/2012/01/ penerapan-mudharabah-mutlaqah-dan.html, diakses tanggal 15 April 2016.

${ }^{32}$ Fatwa DSN-MUI No. 68/DSN-MUI/ III2008 tentang Rahn Tasjily. 
Perjanjian ini untuk membayar kembali angsuran Pembiayaan tepat pada waktunya, dalam hal ini lewatnya waktu saja telah memberi bukti yang cukup bahwa Nasabah telah melalaikan kewajibannya. Untuk hal ini Bank dan Nasabah sepakat untuk mengesampikan Pasal 1238 Kitab Undang-undang Hukum Perdata yang selanjutnya disebut KUHPerdata. Dalam pasal tersebut Nasabah dan Bank sepakat untuk mengesampingkan pasal 1238 KUHPerdata, hal tersebut menurut penulis, diperbolehkan sebab dalam hal ini berlaku asas kebebasan berkontrak, di mana setiap orang dapat membuat kontrak atau jenis apapun tanpa terikat pada nama-nama yang telah ditentukan dalam Undangundang dan memasukkan klausula apa saja ke dalam kontrak yang dibuatnya sesuai dengan kepentingan sejauh tidak bertentangan dengan yang diperjanjikan dan Undangundang yang berlaku.

Sedangkan penerpannya dalam hukum Islam, pada dasarnya diperbolehkan (sama-sama berlaku asas kebebasan beraqad), selama rukun dan syarat yang diperjanjikan terpenuhi, maka aturan yang lain pun boleh dikesampingkan.

d. Aspek Penysunan Kontrak

Terkait dengan penyusunan kontrak, baik dari segi isi maupun format penulisan, menurut penulis masih mengandalkan kerja cepat (menyalinnya secara langsung) tanpa melihat isi dari kontrak pembiayaan yang diadakan oleh nasabah dan pihak bank, padahal kontrak tersebut menjadi dasar paling penting bagi para pihak ketika terjadi masalah terkait pembiayaan yang diakadkan. Akibatnya, banyak dari isi kontrak pembiayaan yang seharusnya berbeda menjadi sama dikarenakan hal tersebut, dan memungkinkan terjadinya permasalahan di antara para pihak, sehingga pembiayaan yang diakadkan dapat menjadi batal dan tidak berjalan sesuai dengan rencana. Untuk itu, di dalam menyusun sebuah kontrak yang sangat penting diperhatikan adalah aspek ke-hatihatian.

\section{KESIMPULAN}

Sehubungan dengan penjelasan di atas, dapat diraih beberapa kesimpulan diantaranya adalah:

1. Mudharabah Mutlaqah merupakan bentuk kerjasama yang dilakukan oleh shahibul mal dan mudharib dimana cakupannya luas tanpa dibatasi dengan spesifikasi jenis usaha, waktu dan daerah bisnis, yang nantinya akan memberikan kebebasan kepada mudharib di dalam mengelola modal dan bisa mendatangkan keuntungan, serta tidak bertentangan dengan prinsipprinsip syari'ah. Pada prinsipnya 
yang berhak mengelola modal adalah mudharib dan pihak pemodal tidak berhak mengelola persekutuan secara mutlak. Sedangkan penerapan mudharabah mutlaqah di bank syariah dapat berupa tabungan mudharabah dan deposito mudharabah.

2. Akad mudharabah mutlaqah dalam praktik perbankan syari'ah, dapat dianalisa dari beberapa aspek:

1) Aspek Pembiayaan

Pada aspek pembiayaan yang tertuang dalam akad/kontrak mudharabah mutlaqah berbeda dengan aplikasi mudharabah mutlaqah secara umum di perbankan syariah.

2) Aspek Jaminan

Jaminan yang tertuang dalam akad/kontrak yang dipaparkan di atas sudah sesuai dengan Fatwa DSN-MUI tentang Rahn Tasjily sebagaimana yang telah diungkapkan sebelumnya.

3) Aspek Kelalaian

Kelalaian Nasabah untuk melaksanakan kewajibannya dalam membayar kembali angsuran pembiayaan tepat pada waktunya, dalam hal ini lewatnya waktu saja telah memberi bukti bahwa nasabah telah melalaikan kewajibannya. Tetapi, aturan tersebut boleh dikesampingkan baik penerapannya dalam hukum konvensional maupun hukum Islam, sebab dalam hal tersebut berlaku asas kebebasan berkontrak/beraqad yang di mana para pihak bebas membuat perjanjian atau jenis apapun serta memasukkan klausula apa saja, selama rukun dan syarat sudah terpenuhi.

4) Aspek Penyusunan Kontrak

Mengenai aspek penyusunan akad/kontrak mudharabah mutlaqah masih mengandalkan kerja cepat (menyalinnya secara langsung) sehingga isi dari kontrak tersebut kadang-kadang tidak sesuai dengan pembiayaan yang diakadkan antara nasabah dan pihak bank.

\section{DAFTAR PUSTAKA}

Agama RI, Departemen, al-Qur'an Transliterasi Per Kata dan Terjemahan Per Kata, Bekasi: Cipta Bagus Segara, 2011.

Ascarya, Akad dan Produk Bank Syariah, Ed. I, Jakarta: PT. Raja Grafindo Persada, 2007.

Burhanuddin S, Hukum Kontrak Syariah, cet. ke-1, Yogyakarta: BPFE-Yogyakarta, 2009.

Djuwaini Dimayuddin, Pengantar Fiqh Muamalah, cet. ke-2, Yogyakarta: Pustaka Pelajar, 2010.

Fatwa Dewan Syariah Nasional Majelis Ulama Indonesia No. 68/DSN-MUI/III/2008, tentang Rahn Tasjily, tanggal 06 Maret 2008. 
Herliyani, Riska, "MakalahEkonomi", dalam http://riskaherliyani. blogspot.co.id/2014/04/ contoh-makalah-ekonomi.html, diakses tanggal 15 April 2016.

Ibnu Majah, Sunan Ibnu Majah, "Kitab at-Tijarah", terj. Lembaga Ilmu dan Dakwah serta Publikasi SaranaKeagamaan, Ensiklopedia Hadits versi Dekstop: Sunan Ibnu Majah, Jakarta: Lidwa Pusaka, 2015.

Karim, Adiwarman, Bank Islam: Analisis Fiqih dan Keuangan, cet. ke-7, Jakarta: PT. Raja Grafindo Persada, 2010.

Knight, Fadly, "Penerapan Mudharabah Mutlaqah Dan Muqayadah Dari Sisi Kewajiban Serta Bagi Hasil Pada Bank Syariah", dalam http: / fadlyknight.blogspot. co.id/2012/01/penerapanmudharabah-mutlaqah-dan. html, diakses tanggal 15 April 2016.
Muhammad, Manajemen Bank Syari'ah, cet. ke-2, Yogyakarta: Unit Penerbit dan Percertakan Sekolah Tinggi Ilmu Manajemen YKPN, 2011.

Muhammad, Manajemen Pembiayaan Mudharabah di Bank Syariah: Strategi Memaksimalkan Return dan Meminimalkan Return dan Meminimalkan Resiko Pembiayaan di Bank Syari'ah sebagai Akibat Masalah Agency, ed. ke-1, Jakarta: Rajawali, 2008.

Mustawa, Janji, "Mudharabah Mutlaqah", dalam http:// www.sanabila.com/2015/08/ mudharabah-muthlaqah.html, diakses tanggal 15 April 2016

Syafi'I Antonio, Muhammad, Bank Syari'ah: Dari Teori ke Prektik, cet. ke-1, Jakarta: Gema Insani, 2001.

Wangsawidjaja Z, Pembiayaan Bank Syariah, Jakarta: PT. Gramedia Pustaka Utama, 2012. 